\title{
Diversity of Natural Enemies on Different Ornamental Plants at Palampur, Himachal Pradesh, India
}

\author{
Suman Sanjta*, Sugandha Sharma and Surjeet Kumar \\ Department of Entomology, CSKHPKV, Palampur, India \\ *Corresponding author
}

\section{A B S T R A C T}

\section{Keyw ords}

Natural enemies,

Ornamental plants,

Palampur

Article Info

Accepted:

17 January 2018

Available Online:

10 February 2018
During survey a total of thirteen species were found belonging to orders viz. Coleoptera, Diptera, Hemiptera and Aranea. The maximum number (10) of species was found of the order coleoptera and maximum number of natural enemies was recorded on rose. The identified species of natural enemies were Coccinella septempunctata, Oenopia kirbyi, Oenopia sauzeti, Hippodamia variegata, Cheilomenes sexmaculata, Chilocorus infernalis, Coccinella transversalis, Coelophora bissellata, Metasyrphus confrater, Orius insidiosus and spiders. Most abundant natural enemy was syrphid followed by Coccinella septempunctata and Hippodamea variegata.

\section{Introduction}

Palampur is located at $32.6^{\circ} \mathrm{N}, 76.3^{\circ} \mathrm{E}$, at an elevation of 1290 meters above mean sea level and represents mid hill sub-humid zone of HP (Singh et al, 2016). This region is suitable for growing different types of ornamental plants and trees, which have great aesthetic value and are grown for commercial value as cut flower, loose flowers and seed purpose. Many different kinds of insects and mites feed on ornamental plants which hamper their aesthetic and economic value (Pal and Sarkar, 2009). To combat these pests, usually insecticides are recommended but by keeping in view the harmful effects of the chemicals on environment and non-target organisms, there is a need to develop some alternate control strategies. Various workers have reported different species of natural enemies on ornamental crops from different regions (Nisha and Gupta, 2010; Sood and Kakar, 1990).

The most abundant group of natural enemies are eulophids, anthocorid bugs, predatory mites, coccinellids, neuropterans, cecidomyiid and spiders (Yee et al., 2000). But from this region, no earlier reports are present on this aspect. In view of this, the present investigation was carried out to study the diversity of the natural enemies in different ornamental crops in the mid hill conditions of Himachal Pradesh.

Materials and Methods 
The present study for determining the distribution, diversity and abundance of natural enemies was conducted on different ornamental plants in the university campus of CSKHPKV, Palampur. Different ornamental crops (Table 1) were sampled to assess the presence of different natural enemies at weekly interval from 7-09-2015 to 28-122015.

\section{Sampling method}

At sampling site, five plants or trees were randomly selected for sampling. From each plant five leaves or flowers were selected randomly for sampling. Selected leaves/flowers were examined and the natural enemies present were counted and identified. Natural enemies were identified with the identified reference specimens present in the laboratory. The data was recorded on weekly intervals from 7-09-2015 to 28-12-2015. For estimating the diversity of natural enemies, the data of individual plants/trees of ornamental plants was pooled together and only the number of adults were counted in all the natural enemies and number of larvae were also taken in case of syrphid flies. For calculation following formula was used:

Relative proportion of ith species $=$

\section{Total number of individuals of ith species}

Total number of individuals of all the species

\section{Diversity indices}

Diversity indices like Shannon diversity index, maximum diversity, species evenness and species dominance was calculated as per procedure given by Shannon (1948) which is described as under:

Shannon diversity $=-\sum$ pi loge pi; where index $(\mathrm{H})$

pi $=$ fraction of ith species

Maximum $=\log _{\mathrm{e}} \mathrm{k} ; \mathrm{k}=$ total diversity index number of species

$\left(\mathrm{H}_{\max }\right)$

Species

evenness $(\mathbf{J})$

Species

dominance

(D)

\section{Results and Discussion}

A total of thirteen species of thrips belonging to four orders i.e. Coleoptera, Diptera, Hemiptera and Aranae in five families viz., Coccinelidae, Staphylinidae, Syrphidae, Anthocoridae and one unidentified family were recorded from different ornamental crops surveyed (Table 2). Among these, eight were identified to species level, two to family level while one was identified to order level. Survey results showed that all sampled crops were harbouring natural enemies.

The identified species of natural enemies were Coccinella septempunctata, Oenopia kirbyi, Oenopia sauzeti, Hippodamia variegata, Cheilomenes sexmaculata, Chilocorus infernalis, Coccinella transversalis, Coelophora bissellata, Metasyrphus confrater, Orius insidiosus and spiders.

Nisha and Gupta (2010) recorded two species of predacious anthocorid bugs, namely Orius niger Wolff and $O$. bifilarus Ghauri on jasmine from Solan. Sanjta (2014) reported that among natural enemies Orius sp. occurred in rose, chrysanthemum and dahlia and spiders were present on bougainvillea, helichrysum and rose. Coccinella septempunctata was found on rose, helichrysum and nastruitium, whereas, Oenopia kirbyi was collected from helichrysum and calendula. 
Table.1 Ornamental crops surveyed

\begin{tabular}{|l|l|l|}
\hline Sr no. & Common name & Scientific name \\
\hline 1. & Rose & Rosa sp. \\
\hline 2. & Marigold & Tagetus spp. \\
\hline 3. & Zinnia & Zinnia elegans \\
\hline 4. & Hydrangea & Hydrangea macrophylla \\
\hline 5. & Calendula & Calendula officinalis \\
\hline 6. & Silver oak & Grevillea robusta \\
\hline 7. & Spirea & Spiraea corymbosa \\
\hline 8. & Sweet william & Dianthus barbatus \\
\hline
\end{tabular}

Table.2 Distribution of Natural enemies

\begin{tabular}{|c|c|c|c|}
\hline Order & Family & Species & Crop \\
\hline \multirow[t]{10}{*}{ Coleoptera } & \multirow[t]{9}{*}{ Coccinelidae } & Coccinella septempunctata (Linnaeus) & $\begin{array}{l}\text { Rose, marigold, } \\
\text { zinnia, calendula, } \\
\text { sweet william, }\end{array}$ \\
\hline & & Oenopia kirbyi Mulsant & Rose, zinnia \\
\hline & & Oenopia sauzeti Mulsant & Rose \\
\hline & & Hippodamia variegata (Goeze) & $\begin{array}{l}\text { Rose, zinnia, sweet } \\
\text { william }\end{array}$ \\
\hline & & Cheilomenes sexmaculata Fabricius & Rose \\
\hline & & Chilocorus infernalis Mulsant & Rose \\
\hline & & Coccinella transversalis Fabricius & Rose \\
\hline & & Coelophora bissellata Mulsant & Hydrangia, \\
\hline & & Unidentified & Spirea \\
\hline & Staphylinidae & Unidentified & $\begin{array}{l}\text { Sweet william, } \\
\text { calendula }\end{array}$ \\
\hline Diptera & Syrphidae & Metasyrphus confrater & Rose \\
\hline Hemiptera & Anthocoridae & Orius sp. & $\begin{array}{l}\text { Marigold, sweet } \\
\text { William, calendula }\end{array}$ \\
\hline Aranea & Unidentified & Spiders & $\begin{array}{l}\text { Rose, marigold, } \\
\text { spirea, silveroak }\end{array}$ \\
\hline
\end{tabular}


Table.3 Diversity of natural enemies on ornamentals

\begin{tabular}{|l|c|}
\hline Species & Relative proportion (\%) \\
\hline Coccinella septempunctata & 18.48 \\
\hline Oenopia kirbyi & 8.7 \\
\hline Oenopia sauzeti & 4.35 \\
\hline Cheilomenes sexmaculata & 10.87 \\
\hline Chilocorus infernalis & 1.09 \\
\hline Coccinella transversalis & 1.09 \\
\hline Hippodamia variegata & 13.04 \\
\hline Coelophora bissellata & 1.09 \\
\hline Unidentified coccinellid & 1.09 \\
\hline Unidentified stayphilinid & 1.09 \\
\hline Syrphid & 30.43 \\
\hline Orius sp. & 6.52 \\
\hline Spiders & 6.52 \\
\hline Total & 100 \\
\hline Shanon index(H) & $\mathbf{1 . 8 9}$ \\
\hline Hmax & $\mathbf{2 . 5 6}$ \\
\hline Evenness(J) & $\mathbf{0 . 7 4}$ \\
\hline Dominance(D) & $\mathbf{0 . 2 6}$ \\
\hline
\end{tabular}

When the relative proportion of the recorded species was calculated, Coccinella septempunctata, Oenopia kirbyi,Oenopia sauzeti, Cheilomenes sexmaculata, Chilocorus infernalis, Coccinella transversalis, Hippodamia variegata, Coelophora bissellata, unidentified coccinellid, unidentified stayphilinid, Metasyrphus confrater, Orius sp. and spiders contributed 18.48, 8.7, 4.35, 10.87, $1.09,1.09,13.04,1.09,1.09,1.09,30.43,6.52$ and 6.52 per cent relative proportion, respectively Shanon index $(\mathrm{H}), \mathrm{H}_{\max }$, evenness (J) and dominance (D) were 1.89, 2.56, 0.74 and 0.26 , respectively (Table 3). Sanjta (2014) observed the highest relative proportion of Coccinella septempunctata among the recorded natural enemies on ornamental plants while in the present study syrphid fly's relative proportion was highest.

\section{Acknowledgment}

Authors are thankful to the Professor and Head, Department of Entomology,
CSKHPKV, Palampur, for providing the necessary facilities required for conducting the present study.

\section{References}

Nisha Devi and Gupta P R. 2010. Anthocorid bugs encountered on cultivated crops and ornamentals, and an attempt to rear Orius niger Wolff under laboratory conditions. Pest Management and Economic Zoology 18: (1) 313-320.

Pal S and Sarkar I. 2009. Pests infesting ornamental plants in hilly region of West Bengal. Journal of Plant Protection Sciences 1(1) : 98-101

Sanjta Suman. 2014. Studies on thrips fauna and their associated natural enemies on different crops under mid hill conditions of Himachal Pradesh. MSc Thesis, Dr YS Parmar, University of Horticulture and Forestry, Nauni, Solan

Shannon C E. 1948. A mathematical theory of communication. The Bell System 
Technical Journal 27: 379-423.

Singh S, Sood K, Kaushal A, Rana RS and Kalia V. 2016. Webgis portal for crop diversification in Himachal Pradesh. International Journal of Agricultural Science and Research 6(1): 321-330

Sood A K and Kakar K L. 1990. Record of insect and non-insect pests on ornamental plants from Himachal
Pradesh. Journal of Insect Science 3(2): 141-145

Yee W L, Phillips P A, Rodgers J and Faber B A. 2000. Abundance and population trends of predators of Scirtothrips perseae and Oligonychus perseae on avocado in Ventura County, California. California conference on biological control II, USA, 195-200.

\section{How to cite this article:}

Suman Sanjta, Sugandha Sharma and Surjeet Kumar. 2018. Diversity of Natural Enemies on Different Ornamental Plants at Palampur, Himachal Pradesh, India. Int.J.Curr.Microbiol.App.Sci. 7(02): 2036-2040. doi: https://doi.org/10.20546/ijcmas.2018.702.243 